\title{
NOTES ON THE FAMILY BRACHYSCELID E, WITH SOME ACCOUNT OF THEIR PARASITES, AND DESCRIPTIONS OF NEW SPECIES.
}

\section{PART I.}

By Walter W. Froggatt, Technological Museum, Sydney.

\author{
(Plates VI.-VII.)
}

These curious woody-gall-forming coccids, one of the most welldefined and interesting groups of the Coccididae, were until lately said to be peculiar to Australia ; but in a recent paper Mr. W. M. Maskell\% places in this family the genus Carteria, several species of which have been described from America, and he forms several new genera for the reception of allied forms found chiefly on the Casuarinas and Melaleucas of this country. The members of the genus Brachyscelis are distinctly Australian, confining their attacks to the Eucalypts, and at one time I believed that each species of eoccid had a partiality for a particular species of Eucalyptus, but observations extending over several years have proved that, though some of the rarer species may keep to one tree, most of them thrive on various Eucalypts ; Brachyscelis ovicola, Schrader, one of our commonest species, has a very wide range over the southern parts of Australia, and is found on at least a dozen very different sorts of Eucalypts.

Mr. H. L. Schrader, a resident of Sydney, was the first to record observations on this group in two interesting communications to the Entomological Society of New South Wales in 1862. $\dagger$

* Trans. and Proc. of the New Zealand Institute, 1891, Vol. xxiv.

† Trans. Ent. Soc. N.S.W. 1862, Vol. i. pp. 1 and 6. 
In these papers he described a number of the common species, illustrated with numerous drawings. These, or almost identical, papers were afterwards published in Germany.*

Finding that these Brachyscelid galls were much subject to the attacks of parasitic Hymenoptera, I first collected them while studying the habits of the Chalcidida for the inquilines they might contain, but becoming interested in their curious homes, I have obtained a large amount of material from various parts of Australia, and have made so many observations both on the coccids and on their parasites that I think it desirable that both should be published together.

The field is large, and I still have the promise of much new material from additional sources, hence in the present communication I propose to deal only with the genus Brachyscelis, leaving the allied genera Opisthocelis and Ascelis for future treatment. Accordingly, for completeness, I have re-described all Schrader's species, and have added eight new species from material obtained from various parts of Australia.

To the following gentlemen, and others mentioned in the paper, I am greatly indebted for specimens, for the identification of the Eucalypts or general information, namely, Mr. J. J. Fletcher, Mr. J. H. Maiden, Curator of the Technological Museum, his assistant Mr. R. T. Baker, and Mr. R. Thornton, of Newcastle, while to the kindness of Mr. A. Sidney Olliff, Government Entomologist, I am indebted the use of a series of drawings of Brachyscelid galls prepared hy his assistant, Mr. C. Fuller, of the Department of Agriculture.

The male galls are small tube-like excrescences with the apex dilated into a bell or cup-like rim, generally bright red or yellow, and are always found upon the leaves or very slender twigs, except when they spring direct from the female galls, as in Brachyscelis pharetrata, Schrader, and several allied species, in which the male galls are attached to the side of the female gall, forming a cockscomb-

* Verhandlungen der K. K. Zoologisch-botanischen Gesellschaft in Wein, Jahrg. 1863, p. 189, Taf. iii. 
like growth consisting of a number of cylindrical tubes massed together, enveloped by a protective overlapping sheath, often many times the size of the female gall. The female galls are variable in shape, green or brown coloured, smooth outwardly, generally oval or oblong, often surmounted with horns or other appendages, and always, with the exception of the cockscomb-like galls which form on the leaf, growing out from the branches or branchlets. Both male and female galls have an opening always at the apex.

The female coccid is a top-shaped, cylindrical, fleshy, white or yellow grub, enveloped in a floury substance secreted by the coccid; the head and thoracic segments are round, much crenulated on the face; it is difficult to say which is the head, as the segment one would take for the head has two rudimentary, three-jointed antennæ, as well as the simple three-jointed fore-legs, which are placed just under them, while the eyes or eye spots are situated close on either side of this overlapping segment. The second and third thoracic segments each bear a pair of short legs, while the abdominal segments are regular, well defined, and taper to a point, the tip being surmounted with a pair of pointed anal appendages, which Schrader says are used to keep the orifice of the gall clear of obstructions; but I consider it more likely that they are of use to the coccid in drawing herself towards the opening. The coccid lies in the fleshy gall, which is sometimes a quarter of an inch thick, head downwards, the tail pointing outwards; she is generally smaller than the gall chamber, and has plenty of room to move backwards and forwards. When full grown the males emerge from the neighbouring galls, and by means of their slender, pointed abdomen impregnate the imprisoned female through the apical orifice, through which the latter can exsert her anal appendages.

After impregnation the males die, and the females become a mass of eggs, from which the young larvæ soon emerge, crawling through the opening in the gall and leaving the empty shell of their mother behind in the ripe gall. The larvæ [e.g. of Brachyscelis munita] are microscopic, yellow, active creatures, having a circular, shield-like body margined with a fringe of cilia, distinct eyes, antennæ, and legs. They move about quickly, and those 
that survive after escaping from the gall immediateiy bury themselves in the bark or leaves, and commence a fresh crop of young galls. I believe that the virgin female is capable of bringing forth larvæ, as I have frequently found clusters of active larvæ in the chamber with the perfect and evidently unimpregnated female coccid.

The male of Brachyscelis [e.g. of B. munita] is a very beautiful little two-winged creature, not much more than half a line in length, having many jointed antennæ as long as the whole length of the head, thorax, and abdomen combined, terminating in three hairs or filaments ; the joints of the antennæ are short and the divisions indistinct. The eyes are black, globular, and very prominent, divided from each other, as looked at from above, by a wedge-shaped bar between, widest in front. The prothorax is rounded, broadest in front, bright yellow, and shining; the wings are large, round at the tips, constricted at their junction with the shoulder, and bear a strong costal (transverse of Ashmead) nervure with a fainter one (discoidal of Ashmead) across to the apex of the under side of wing, forming an elongated $V$. The legs are long, the femora robust, the tibiæ slender, the tarsi short. The abdomen consists of eight constricted segments, and a small pointed anal one bearing the genitalia; from either side of the eighth segment shoots out a long white filament, twice the length of the whole insect; the whole covered with scattered white hairs.

The perfect niales are very delicate, and their galls are so small that it is very difficult to breed them out; but of three very distinct species of galls from which I have obtained specimens of the insects, I can find no difference in any particular in the perfect males. The characters of the males, therefore, seem to me unımportant in discriminating species. To a casual observer the female coccids would appear very much alike, but thongh there is a very strong general resemblance in most cases, there are, besides the difference in form, several very good specific peculiarities: firstly, in the form, shape, and situation of the anal appendages; secondly, in the hairy coating on the abdominal segments ; and thirdly, in the number, shape, and regularity of the distribution of the 
tubercles and fine-toothed spines covering the upper side of the abdominal segments.

The female galls of the different species are usually very distinct in form from each other; and though with single specimens of some it might be difficult to determine the species from the gall alone, yet in a large series they are unmistakable.

The female galls are all very much liable to attacks by parasites, and many of the minute micro-hymenoptera belonging to the Chalcididce and Proctrotrupidce will be found to emerge from the outer skin of the gall, possibly being parasitic upon smaller plant-eating larvæ which they have destroyed. Other parasites lay their eggs upon or in the coccid, the larvæ which hatch therefrom feeding upon her fleshy body, and undergoing their metamorphoses in her skin. I have obtained 100 specimens of a small black Chalcid from a single dead Brachyscelid. The larvæ also of several different moths likewise manage to obtain a footing inside the galls, true inquilines, for they soon smother the rightful owner. I once opened a gall of B. ovicola in which I found an exceedingly active moth larva together with a live coccid; but the former was having much the best of it, for the coccid was not more than half the size of a number of its companions taken from the same bunch of galls. I have never been able to breed out the perfect moths from these larvæ, for as the galls become dry the food supply fails them and they die.

A large number of plant-eating beetles are also obtainable from the galls, most of them belonging to the Curculionida, chief among which are members of the genera Haplonyx, of which I have bred five different species, and Rhadinosomus, a remarkable, goat-like little Curculio. Several others belonging to the genus Omadius (Family Cleridae) were hatched out of the galls of $B$. minor.

Great numbers of young Eucalypts are annually attacked by these insects, which if they do not in consequence actually die become stunted in their growth from the foliage and young growth being robbed of so much sap, and tissue diverted from the proper channel, to form these peculiar excrescences; it is therefore of 
some economic interest for us to be acquainted with the habits and mode of growth of the Brachyscelids together with the parasites by which they are kept in check, for as they come forth in such countless numbers and in their earlier stages mine out of sight, they might under favourable circumstances become a serious pest in plantations of young Eucalypts.

Brachyscelis duplex, Schrader, Trans. Ent. Soc. N.S.W. 1862, Vol. i. p. 5, pl. II. fig. A, h, l, o, s.

ㅇ. Gall springing from the branch on a square four-sided stalk varying from a quarter to half an inch in length, swelling out from this into a four-sided gall with ridged edges; $1 \frac{1}{2}$ inches in diameter ; $2 \frac{1}{4}$ inches in length from top of stalk to apical orifice; the latter a broad and very narrow slit, on either side of which the gall is prolonged into a flattened broad horn, which is often 5-6 inches long; as many as four of these large galls may be on a small twig a few inches long. Chamber containing coccid long, cylindrical, and pointed at both ends; the walls 4 lines in thickness and very solid.

ㅇ. Coccid golden yellow; apical segments broad, slightly depressed in centre; legs very short, the joints of the middle and hind legs almost globose, tarsal claws small and blunt; abdominal broad and well defined, of a uniform breadth until about the third above the anal segment, thence forming a blunt rounded base from which the anal segment, which has a $v$-like mark on either side, projects, bearing two long slender anal appendages widely apart, $1 \frac{1}{2}$ lines long, the pointed tips turned outwards and surmounted with three long filaments or hairs; long scattered hairs all over the abdominal segment, forming distinct tufts on the lower part of the outer edges of the last four apical segments; the upper side of the apical four marked with fine tubercles; the first with very small and scattered tubercles, the following and anal segments with the tubercles in regular rows, conical, spinose, all the segments fringed along the outer edges with tufts of long white hairs. Length 12 lines, at widest point of thorax, $5 \frac{1}{2}$ lines broad. 
o. Gall growing from the leaves and also from the horns of the young female galls; not cylindrical, but four-sided, but instead of the circular rim at apex, divided into two flat sides opening out into a $\mathrm{v}$-form. Height 3 lines, diameter $\frac{3}{4}$ of a line.

Hab.-Neweastle, on Eucalyptus sp. (R. Thornton); Lawson, Blue Mts., on E. sp. (E. Palmer).

In Schrader's paper this species is very briefly described, and the gall of the specimen figured has very short horns, whereas in most well-shaped galls the latter are often six inches in length. I had received several dried specimens of this fine gall on various occasions, but without any information as to where they were obtained, and had never obtained any fresh green ones until a short time ago, when among a collection of galls and botanical specimens received by the Curator of the Technological Museum from Mr. R. Thornton of Newcastle, were about a dozen very good fresh specimens of the gall of this Brachyscelid.

Brachyscelis munita, Schrader, l.c. p. 6, pl. ir. fig. x.

․ Gall sessile on twigs, round at base, but with four distinct angles above, from the corners of which arise a long horn broad at base, slender at the tip, and generally curling backwards; height 10 lines, width 7 lines, horns 2 inches in length; walls of chamber solid but thin; chamber broad, oval, and conical at apex, apical orifice circular, small and situated in the centre of apex, where the four ridges running back from the horns conjoin.

Q. Gall of slender variety stalked, the stalk broad, angular; the surmounting gall four-sided, swelling out from and about twice the length of the stalk, and broadest at apex; from each angle springs out a straight cylindrical horn, broadest at base and attenuated towards the tip; length of gall $1 \frac{1}{2}$ inches, including the stalk, width at apex of stalk 3 lines, width at base of horns 6 lines, horns often attaining a length of 6 or 7 inches; apex of gall flat or slightly rounded between the horns.

The measurements are very variable, as the galls can be found of all shapes and sizes growing in great clusters, sometimes one growing out from another. I should consider this an aborted 
variety of the more regularly formed one, for when a tree is attacked by this one its sap becomes so impoverished by the quantity of galls it has to support that they in turn become slender and attenuated from want of building material. This variety grows upon Eucalyptus robusta, the large, succulent leaves of which seem to be attacked by many insect larvæ.

. Coccid dull yellow to semi-transparent; 8 lines long, 5 lines broad; head and thoracic segments much wrinkled; legs small and short; abdominal segments short and broad, thickly clothed towards the apex and sides with long yellow hairs; anal appendages short, blunt, narrowly divided at base, turned slightly outwards at the tip, upper side rather flat; anal segments densely clothed with long yellow hairs; two lower thoracie and first abdominal segment covered with very fine ferruginous tubercles, the remaining abdominal segments margined above the apex with a row of fine pointed tubercles, largest and stoutest towards the tip.

o. Galls growing in a cluster on a small twig, the cluster composed of several hundred short twisted or straight male cells sticking out at all angles; many of them are doubtless sterile; slightly dilated at the apex and of a bright red colour, the whole forming an irregular rounded or oval mass, often over an inch in diameter.

In the straight-horned variety the male galls are clustered together in irregular masses, but never in such large numbers or so closely together, each gall standing out and more independent of the others.

This is a well-defined species, and does not vary much from two forms which are evidently variations caused by the stems being attached by only a few coccids or else by a large number; the large typical form is not common about Sydney, and is more an inland species, while the small variety seems to be much the commonest in the neighbourhood of Sydney.

In the Ent. Mo. Mag. (1880, Vol. xvii. p. 145), there is an article on "Eucalyptus galls," by Mr. R. McLachlan, in which he describes and figures two galls handed over to him by Dr. M. F. 
Masters, Editor of the Gardener's Chronicle, who received them from Baron von Mueller, Government Botanist of Victoria. With the first, which is a slender, finger-like gall and is the production of a Cynips or Cecidomyia, we have nothing to do; but the second is a bunch of the female galls of Brachyscelis munita, though it is described as the gall of a moth, and Mr. McLachlan says of it : "Fortunately in this instance it is possible to fix with certainty the order to which the gall-maker belongs. Baron von Mueller extracted larvæ from some similar galls and forwarded them in fluid. They are Lepidopterous." He minutely describes the gall, and considers the apical orifice as a breathing pore for the larvæ, left open on account of the walls of the galls being so solid.

Hab. - Botany, on E. robusta (W. W. Froggatt); near Parramatta, on E. sp. (J. J. Fletcher); Wellington, on E. sp. (W. W. Froggatt); Newcastle (R. Thornton); Melbourne, on E. sp. (C. French).

From some specimens obtained from near Parramatta by Mr. Fletcher I bred one specimen of Haplonyx ustipennis, Pascoe (Journ. Linn. Soc. 1870, x. p. 488); the larva was an obese white grub; though I opened the gall before I noticed the grub, it throve and came out a perfect insect three months later.

\section{BraChysCelis TRICORNIS, n.sp.}

\&. Gall triangular, the angles rounded, smallest at base where attached to the twig, sessile, swelling out and widest at apex ; the horns standing out at right angles, sword-shaped, very thick and swollen at base, terminating in a broad tip; gall 10 lines high, 9 broad at base of horns; length of horns, $2 \frac{1}{2}$ to 3 inches; apical orifice very small, circular, situated in centre between the horns; chamber containing coccid rounded at base, of a uniform width for two-thirds of height, coming to an obtuse point at the apex ; walls of chamber of a medium thickness.

o. Coccid yellow to dull brown, rounded at apex; thoracic segments well defined; basal joint of middle and hind legs short and globose, second joint short, cylindrical ; tarsal claw sharp and hooked; abdominal segments narrow and tapering to a sharp tip 
with a few scattered hairs on apical margins; anal appendages ferruginous, stout, close together at base, but cleft in a wedgeshaped opening outwards at the apex, truncate at tips ; upper side of abdominal segments with a few long hairs on apical portion, outer edges thickly fringed with long hairs, last four with a short irregular row of tubercles along their apical margin; length $7 \frac{1}{2}$ lines, $4 \frac{1}{2}$ broad.

o. Gall unknown.

Hab.--Rookwood, on the broad-leaved iron-bark, E. siderophloia (J. J. Fletcher).

This is a distinct species closely allied to B. munila, but the difference in shape and in the number of the horns renders it very easily recognisable.

Brachyscelis pileata, Schrader, l.c. p. 3 , Pl. i. tig. $1, a, h$, and $l$.

o. Gall narrowest at base of attachment to the twig, generally growing with the apex inclined downwards towards the branch, elongate-oval in form, but truncate at apex, which forms two broad lips separated by the narrow slit-like apical orifice; length, 14 to 16 lines; diameter, 7 lines; chamber containing coccid narrow at base, jug-shaped at apex, wall thin. When immature the gall is enveloped in a reddish cap covering the gall and produced into a slender horn often several inches in length, which appears to be an abnormal growth of the bark of the twig above the burrowing coccid; as the gall increases in size this envelope becomes a dry papery substance, splits off at the base, and drops off when the gall is about three-parts grown.

o. Coccid dull brown to almost transparent; head and thoracic segments rounded at base ; legs rather short ; tarsal claws black ; abdominal segments narrow, not tapering, but broadly rounded towards the apex, each segment ornamented at the apical sides with a tuft of white silky hairs; anal appendages situated on either side of the broad anal segment, separated from each other at base, long, slender, black, and each surmounted with three long stout hairs; upper side of head and thoracic segments much depressed, often almost flat, covered with fine white hairs; 
abdominal segments clothed with long white hairs, which overlap the junction of the segments and form large tufts at the apex of each; the 2nd and 3rd thoracic segments with numerous small scattered spines; 1st and 2nd abdominal segments with an irregular double row of spines; 3rd with a regular row of close short spines in clusters of twos and threes, with three longer stout spines at either margin; 4 th and 5 th with the spines stouter, disposed either in twos or threes, with two longer curved spines at either margin ; 6th and last above the anal segment carrying four large stout spines and a single longer one on either side; length $6 \frac{1}{2}$ lines, 4 lines broad.

o. Gall reddish-brown, short and broad, growing on the leaves, pear-shaped and often ribbed, the apex broadest, this in the mature gall opening out into a bell-mouthed rim; $3 \frac{1}{2}$ to 4 lines high.

Hab.-Rose Bay, on E. piperita (W. W. Froggatt); Mossman's Bay, on E. sieberiana and on E. capitellata (W. W. Froggatt); Newcastle, on $E$. $s p$. (R. Thornton).

This, the common Sydney species, is confined to the coast country, generally attacking small trees, which, when once infested, produce galls year after year. I have noted a tree at Double Bay for the last four years which has had a large crop every season.

The galls obtained from $E$. capitellata are very much broader and more squat than the typical ones, with the walls very stout and thick; and when immature have very small spined caps unlike those on E. piperita.

Brachyscelis minor, n.sp. Pl. vi. fig. 1.

q. Gall round at base, constricted about two-thirds up from base, and truncate at apex, the small and circular apical oritice placed in the centre of a shallow depression; walls of chamber moderately thick, solid, the chamber oval, coming to a sharp point at the apical orifice; length 7 lines, diameter $4 \frac{1}{2}$ lines.

o. Coccid dull yellow, round at apex and coming down to a sharp tip; plump and top-shaped; legs slender; abdominal segments very regular and distinct, clothed with fine long hairs, thickest on the sides; anal appendages short, close together, 25 
opening out slightly at the apex; upper side all clothed with fine white hairs lightly scattered over the head and thoracic segments, very close and dense on the abdominal segments, the latter with a row of small acuminate tubercles along their lower margins; anal appendages surmounted on the tip with several fine hairs; 5 lines long, 3 lines wide.

f. Gall 3 lines high, width $\frac{1}{2}$ line; bright red; tubular, with a disc-like rim at the apex.

I have bred the male coccid from these galls, but under the microscope I could not find any difference between them and those of $B$. pharetrata.

Hab.-Botany and Berowera on E. homastoma; Wollongong on a stunted Eucalyptus (W. W. Froggatt).

This is a rather small gall that might be taken for a small variety of $B$. ovicola, but is very constant in its form; while the female coccid is very distinct from that of the latter species.

I obtained a great number of the galls of both sexes on the leaves and twigs of a number of small stunted Eucalypts growing on the hillside opposite the railway station at Wollongong; the twigs were covered with the little seed-capsule-like galls, sometimes clustered together in bunches of a dozen or more, while the leaves were completely aborted by the immense number of male galls growing out of them. In other localities I have only found them scattered in twos or threes on the branches.

Brachyscelis variabilis, n.sp. Pl. vir. fig. 2.

o. Gall oval, sessile, growing directly from the stem, about twothirds from base constricted to a third, the apex curved inwards; $2 \frac{1}{4}$ inches high, $1 \frac{3}{4}$ inches wide; dome $\frac{3}{4}$ inch high, 1 inch wide; walls of chamber above the base 7 lines in thickness; top of true gall almost flat at the apex, with a small circular orifice; above this the dome-shaped covering springs up, with thin walls enclosing an irregularly-shaped cavity with a large opening on top above the orifice of the lower chamber.

The above measurements are taken from an exceptionally fine specimen; many are much smaller, more rounded than pear-shaped, 
and much aborted on the outside cuticle by the mining of parasitic Hymenoptera.

Q. Coccid dark yellow ; 8 lines long, 5 broad, rounded at head and thoracic segments, swelling out on the sides in a line with the middle pair of legs ; fore-legs more prominent than usual ; all the legs small, ferruginous, and projecting out from the body; abdominal segments covered with fine silky hairs, which are very dense on the last three segments; anal appendages very short and stout, close together at the base, straight, but slightly open at the apex, the tip of each concave, armed with a fine tooth on both sides; on the upper side the abdominal segments clothed with fine white hairs; the last three segments only margined across the lower edge with a row of very small regular acuminate tubercles.

†. Galls small, reddish, tubular; 2 lines long, with a bell-shaped swelling at the apex.

Hab.--Thornleigh, near Sydney, on E. piperita (W. W. Froggatt); Newcastle, on $E$. sp. (R. Thornton); Cambewarra, on $E$. sp. (W. Bäuerlen) ; Lismore, on E. sp. (R. Helıns).

This is a very variable species, but is very constant in having the chamber walls very thick at the base, the apex surmounted by a dome-like cup rising above the true apical orifice and forming another cavity with a large irregular opening at its apex. They are usually found singly, often on stout stems, but sometimes in clusters, and appear to have a wide range over the coastal districts of New South Wales.

Some immature specimens obtained lately at Hornsby give some idea as to how this curious double-celled gall is constructed; they are generally formed in a stout stem of a young sapling; the true gall is formed of the woody substance of the stem, while the bark growing rapidly covers the outer sides and rises above the wooden portion of the gall, a cavity forming on the apex between the bark and the growing gall.

Brachyscelis conica, n.sp. Pl. vi. fig. 3.

ㅇ. Gall cylindrical, rounded at the base, generally widest in the middle and tapering towards the apex, which is truncate, some- 
times ovate; variable in form, fresh galls always of a bright green colour with a granulated surface; a growth of browncoloured wood forms several distinct rings at the apex surrounding the apical orifice; the latter small, circular, situated at bottom of a shallow depression; walls of chamber containing female solid, chamber long, narrow, cylindrical; length 14 lines, diameter 8 lines.

o. Coccid dull yellow, head and thoracic segments rounded on top, large and not much wrinkled; legs short and thick, posterior ones prominent; abdominal segments attenuated towards the anal segment, lightly clothed with hairs on the sides; anal appendages short and blunt, deflexed outwards, forming a triangle at tip; the head and thoracic segments on upper side rather flat; a few scattered tubercles on the first abdominal segments, the rest of segments each armed with a regular row of fine sharp spines; length 9 lines, breadth 4 lines.

5. Gall large and tubular, swelling out into a regular bell-shaped apex ; generally growing out from the small twigs, but sometimes upon the leaves; length 5 lines, diameter 1 line.

Hab.-Yass, Goulburn, and Cooma, N.S.W., on E. viminalis (W. W. Froggatt); Gippsland, Victoria, on E. sp. (F. O. Hill).

This gall is very plentiful in the Goulburn and Yass districts, growing upon several of the White Boxes, and also has a much wider range, as I have had a number sent me from Gippsland, collected by my friend Mr. F. O. Hill, of Melbourne.

This species is much attacked by a small hymenopterous parasite, the larvæ of which, after destroying the female coccid, form little oval wooden cocoons, often quite filling up the chamber; the lepidopterous larvæ so common in B. munita are also common in this gall.

Of parasitic Coleoptera I have bred out several specimens of that curious goat-like little Curculio Rhadinosomus Lacordairei, Pascoe, which I have also obtained from the female galls of $B$. minor. 
Brachyscelis pomiformis, n.sp. (Pl. vir. fig. 7.)

Q. Gall apple-shaped, slightly depressed at the base where attached to the branch, swelling out on the sides and slightly narrowing towards the top; at the apex is a circular depression or little pit about 3 lines in depth, in the centre of which is the very small orifice; colour greyish-brown; diameter 3 inches, height 2 inches; thickness of walls $\frac{1}{3}$ to $\frac{1}{2}$ inch; size of chamber doubtful.

The smaller ones almost spherical in shape, but the large ones more squat at the base.

Only one gall contained the remains of a female; the anal segments appear to be robust and dark coloured.

o. Gall unknown.

Hab. -Torrens' Creek, N.Q., on E. sp. (- Chisholm); Barrier Range, King's Sound, N.W.A., on E. sp. (W. W. Froggatt).

This remarkable gall is a northern species, not found in the vicinity of Sydney ; my specimens were obtained at King's Sound, N. W. Australia, where they grew on a stunted Eucalypt under the Barrier Range, about a hundred miles inland. The natives there eat the large gall, which when fresh is soft and acid, not unlike a sour apple, and they look upon the fat white Brachyscelid as a very dainty morsel. Through the kindness of $\mathrm{Mr}$. J. H. Maiden, I have received a very large specimen of the gall obtained by Mr. Chisholm, of Torrens' Creek, near Charters Towers, N. Queensland, together with an interesting letter from the latter gentleman, in which he says "it is known as the "blood-wood apple,' and the blacks are very fond of eating it."

Brachyscelis ovicola, Schrader, l.c. p. 5, pl. ii. fig. 3, $a, e, f$.

o. Gall pale green, smooth, narrowest at base of attachment to twig, forming an oval with a slight depression at the apex, in the centre of which is situate the apical orifice, which is minute and circular ; length 14 lines, diameter 9 lines; thickness of chamber walls 2 lines; chamber round at the base, coming to a sharp point just below the apical orifice.

q. Coccid pale canary-yellow, shining when the white floury excretion is brushed off; centre of the first segment rounded at 
top, widest in the middle ; central pair of legs, thoracic segments, and head very distinct; legs, eyes, and antennæ ferruginous; abdominal segments narrow, rapidly tapering to a point, the last four apical segments ferruginous; anal segment long and slender; anal appendages black, deeply divided but cohering, long, sleuder and pointed; on the upper side all the abdominal segments covered with fine hairs, the thoracic segments and first abdominal segments covered with fine tubercles; on the rest of the abdominal segment these tubercles produced into small ferruginous coloured spines, which form regular rows along the lower margins of these segments, but half hidden by the fine hairs clothing the body; length 8 lines, diameter $4 \frac{1}{2}$ lines.

§. Gall formed on the leaves; reddish-brown; short and broad; $2 \frac{1}{2}$ lines in height, slightly ridged and of a uniform thickness; the apical opening large but not much dilated or bell-mouthed.

Hab.-Wellington, N.S.W., on E. sp. ; Bendigo, Victoria, on E. gracilis, and on E. leucoxylon (W. W. Froggatt).

Of parasitic Coleoptera (Family Curculonidce) I bred a single specimen of the beetle Haplonyx myrrhatus, Pascoe, from a gall of this species obtained in the Whipstick scrub, near Bendigo, and I noticed a large number of galls obtained in this locality bearing circular openings through which the perfect beetles had already escaped.

This species has a wide range over the southern portion of Australia, and forms its galls upon a number of very distinct species of Eucalypts. Though not very common in the neighbourhood of Sydney, it is often met with on the white gums in the western country; like most species it grows on the young twigs, but I have several fine specimens growing out of young flower buds.

In consequence of the thick fleshy walls of the gall being much mined by the attacks of parasitic Chaleids, they often swell out into great puffy masses, losing all their fine oval contour, while the helpless female is also subject to inquilines that either eat or crowd her out. 


\section{Brachyscelis Baeuerleni, n.sp. (Pl. vit. fig. 4.)}

․ Galls round, clustered together in bunches of three or four at intervals along the branch, broadly attached to the twig, depressed at the apex ; 9 lines high, 7 lines wide ; the walls consisting of a double shell, the inner one hard and thin, the outer one thick and spongy ; sometimes a very slight cavity on either side of the apical orifice, the point of the inner shell carrying the orifice level with the top of the gall; chamber broad, rounded, conical at apex; orifice very small and situated in centre of a hollow.

c. Coccid dark yellow, round at apex, the first three thoracic segments very large; abdominal segments very small; head and thoracic segments very much wrinkled; legs short and globose; abdominal segments regular, narrow, lightly fringed with fine hairs, the apical ones ferruginous; anal appendages black, close together, short, thick, pointed, and slightly parted at the tips, rather rugose on their outer edge; on the upper side the last thoracic and all the abdominal segments armed with a regular row of fine acuminate tubercles; length 7 lines, width 4 lines.

o. Gall unknown.

Hab.-Ballina, on E. sp. (W. Bäuerlen).

I have seen only one lot of these galls, which were obtained by the botanical collector of the Technological Museum in the Richmond River district; they are quite unique, and I have great pleasure in dedicating the species to the finder, my old comrade in arms Mr. William Bäuerlen.

Brachyscelis rugosa, n.sp. (Pl. vil. fig. 5.)

o. Gall sessile, dull brown, hemispherical in shape, externally very rugose, warty and irregularly ridged; depressed at apex ; double-shelled, the inner sheath very thin and hard, the enveloping husk spongy, containing numerous small cavities between it and the inner shell; opening at the apex above orifice in first shell rough and irregular; apical orifice small, circular; length 8 lines, diameter 8 lines.

q. Coccid dull yellow, broad and squat; the head and thoracic segments wrinkled, rather flat; the second thoracic segment 
rounded and rising up on either side to a level with the top of first segment, which is depressed at top; legs small; abdominal segments very small, lightly fringed on the margins with fine hairs, and coming to a point above the anal appendages, which are ferruginous, black at tips, short and thick, lying close together, and rugose on their outer margins; upper side of abdominal segments covered lightly with fine hairs and each armed with a row of fine tubercles; length 6 lines, $4 \frac{1}{2}$ wide.

§. Gall unknown.

Hab.-Allalong, N.S.W., on E. sp. (W. W. Froggatt).

These galls were obtained by me in considerable numbers upon the twigs and stems of a stunted Eucalypt at Allalong, in the Maitland district. I have never seen any other specimens.

Brachyscelis pharetrata, Schrader, l.c. p. 4, pl. i. fig. 2,o-8; pl. ii. fig. $3, g$.

ㅇ. Gall springing from the leaf, generally on the midrib, narrow at base of attachment, swelling out in the middle and coming to a more or less conical point at apex; the apical orifice small; length 5 lines, $2 \frac{1}{4}$ diameter.

․ Coccid yellow, obese, top-shaped; the head and thoracic segments spherical; legs small; abdominal segments very narrow and regular, thinly clothed with fine hairs on the underside, but much thicker on the upper side; no spines or tubercles on the upper side of the abdominal segments ; the anal appendages black, short, deeply divided; tips thick and stout; length $3 \frac{1}{2}$ lines, diameter $2 \frac{1}{2}$ lines.

o. Galls in large irregular mass appearing upon the side of the female gall after it is nearly mature; it is generally smooth on the outside, which consists of an overlapping sheath, often when full grown brilliantly tinted with red and yellow colours; in this sheath are a mass of small tubular cells opening outwards, each containing a male larva, the whole being five or six times the bulk of the small female gall; length of tubes 3 lines.

๙ิ. Coccid pale yellow with large grey wings and black eyes; length $\frac{1}{2}$ line. 
The description given of the specimens bred from $B$. munita would not differ in any particular from that of this species.

Hab.-Botany, on E. sieberiana; Berowera, on E. corymbosa; Mossman's Bay, on E. capitellata (W. W. Froggatt); Newcastle, $E$. sp. (R. Thornton); Cambewarra, on E. sp. (W. Bäuerlen).

This is known as the "cockscomb gall," from the cock's-comb-like appearance of the male gall mass. It is not an uncommon gall about Sydney, and I have watched a patch of trees at Botany attacked by this coccid, from which I obtained galls for several years, but they have been all destroyed by the larvæ of Haplonyx Hopei, which get inside and feed upon the female galls.

Of parasitic Coleoptera (Fanily Curculionida) I have bred Haplonyx Hopei, Bohm., from the galls of this Brachyscelid.

Schrader in his paper gives a drawing of the male galls of this species on the twigs, but there must be some mistake, as I am certain that the male galls are always produced upon the females.

\section{Brachyscelis Thorntoni, n.sp. (Pl. vi. fig. 6.)}

Q. Gall small, slightly rounded at base, cylindrical, faintly ribbed on the sides, narrowing towards the apex, which is truncate, the apical orifice small, encircled by a slight ridge; length 8 lines, diameter $1 \frac{3}{4}$ lines; chamber containing coccid conical, walls solid but thin.

Q. Coccid pale yellow, cylindrical, rounded at top of head and thoracic segments, which are much wrinkled; legs small; abdominal segments narrow, divisions sharply defined, lightly fringed with hairs on the outer margins ; coming to a sharp point at anal segment; anal appendages long, slender, distinctly separated at the base, but close together until close to the tips, where they open outwards, tips truncate; upper side shining, head and thoracic segments with a few scattered hairs; abdominal segments fringed on the outer edges with short hairs; 1st segment spineless; 2nd and 3rd with a few scattered spines along the centre; 4 th and 5 th with a regular line of spines along the apical edges; 6 th with row of stout spines along the apex ; anal segment ferruginous, slender ; length 4 lines. 
f. Galls growing out from the side of the $o$ gall just below the apical orifice into a large mushroom-like mass, the outer side covered with a wrinkled epidermis ; on the under side the tubular male galls are all separated from each other, short, straight, reddish-brown in colour, most of them toothed at the apex; a very fine specimen obtained from Newcastle district is 17 lines at its greatest width and contains over three hundred male galls in the one mass.

Hab. - Newcastle, on E. sp. (R. Thornton).

This remarkable gall was found in the Newcastle district by Mr. R. Thornton, the well-known bush naturalist, to whom I am indebted for a very fine collection of several species of Brachyscelid galls.

It is closely allied to B. pharetrata and B. nux, Olliff, but differs considerably from both. The female galls often spring out in clusters of five or six at the base of the leaves, and when immature look like a bunch of finger-shaped excrescences.

\section{EXPLANATION OF PLATES.}

Fig. 1.-Brachyscelis minor: $a$ and $b$ two stages of female galls ; $c$ female galls ; $d$ adult female coccus.

Fig. 2.-B. variabilis: female gall whole $(e)$ and in section $(f)$.

Fig. 3. - B. conica : $g$ female galls; $h$ male galls.

Fig. 4.-B. Bäuerleni: female galls.

Fig. 5.-B. rugosa: female galls $i$, and adult female coccus $j$.

Fig. 6.-B. Thorntoni: female galls.

Fig. 7. $-B$. pomiformis: $k$ female gall seen from above; $l$ under view showing attachment to twig.

(All figures of the natural size.) 


\section{$2 \mathrm{BHL}$ Biodiversity Heritage Library}

Froggatt, Walter W. 1893. "Notes on the family Brachyscelidae, with some account of their parasites, and descriptions of new species." Proceedings of the Linnean Society of New South Wales 7, 353-372.

https://doi.org/10.5962/bhl.part.26060.

View This Item Online: https://www.biodiversitylibrary.org/item/29776

DOI: https://doi.org/10.5962/bhl.part.26060

Permalink: https://www.biodiversitylibrary.org/partpdf/26060

\section{Holding Institution}

MBLWHOI Library

\section{Sponsored by}

MBLWHOI Library

\section{Copyright \& Reuse}

Copyright Status: NOT_IN_COPYRIGHT

This document was created from content at the Biodiversity Heritage Library, the world's largest open access digital library for biodiversity literature and archives. Visit BHL at https://www.biodiversitylibrary.org. 